\title{
MENDETEKSI FAKTOR PENENTU STRUKTUR MODAL PADA SUB SEKTOR PERDAGANGAN BESAR (WHOLESALER) DAN RETAILER DI INDONESIA YANG GO PUBLIK.
}

\author{
Jaka Suharna, Eka Bertuah \\ Fakultas Ekonomi dan Bisnis, Universitas Esa Unggul \\ Jalan Arjuna Utara No. 9, Kebon Jeruk, Jakarta 11510 \\ jaka.suharna@esaunggul.ac.id
}

\begin{abstract}
Abstrak
This research aims to detect the determining factor of capital structure in Wholesaler and Retailer subsector in Indonesia. There are 44 companies used as the research sample; they are the wholesaler and retailer companies as listed in BEI (Indonesia Stock Exchange) during 2013-2017. The data analysis used logistic regression and ANOVA test. The result shows that the sales growth and profitability could be the determining factor in company capital structure. The sales growth has negative effect toward the capital structure. This implies that the higher sales growth, the lesser the debt usage. Besides, profitability has negative effect toward the capital structure. This indicates that the companies with profitability increased would reduce the debt usage as the profit would be used as funding to keep the innovation going in the company. The research result also shows that there are no differences in firm's values between the high-debt-funding companies and the low-debtfunding companies. This supports the Modigliani-Miller theory which stated that the capital structure doesn't affect the firm's values.
\end{abstract}

Keywords: capital structure, sales growth, profitability

\begin{abstract}
Abstrak
Penelitian ini bertujuan untuk mendeteksi faktor penentu struktur modal pada sub sektor Wholesaler dan Retailer di Indonesia dan selanjutnya menguji apakah keputusan pendanaan berdampak terhadap nilai perusahaan. Sampel penelitian yang digunakan dalam penelitian ini sejumlah 44 perusahaan yaitu perusahaan pada sub sector Wholesaler dan Retailer yang listing di BEI selama tahun 2013 - 2017. Adapun analisis data yang digunakan adalah regresi logistic dan uji beda anova. Hasil penelitian menunjukkan bahwa pertumbuhan penjualan dan profitabilitas dapat menjadi faktor penentu struktur modal perusahaan. Pertumbuhan penjualan berpengaruh negatif terhadap struktur modal. Hal ini mengimplikasikan bahwa tingkat pertumbuhan penjualan yang tinggi akan mengurangi penggunaan hutang. Disamping itu profitabilitas berpengaruh negatif terhadap struktur modal. Hal ini mengimplikasikan bahwa perusahaan yang memiliki profitabilitas meningkat akan mengurangi pendanaan hutang, profit akan digunakan sebagai dana untuk terus melakukan inovasi. Hasil penelitian juga menunjukkan bahwa tidak terdapat perbedaan nilai perusahaan antara perusahaan yang memiliki pendanaan hutang yang tinggi dengan perusahaan yang memiliki pendanaan hutang yang rendah. Hal ini mendukung teori Modigliani-Miller yang menyatakan bahwa struktur modal tidak berpengaruh terhadap nilai perusahaan.
\end{abstract}

Kata kunci: Struktur Modal, Pertumbuhan Penjualan, Profitabilitas

\section{Pendahuluan}

Persaingan usaha yang ketat perusahaan harus memiliki keputusan pendanaan yang tepat, dimana perlu adanya peran manajer dalam menentukan struktur modal yang optimal. Struktur modal yang optimal dari perusahaan akan mampu meminimalkan biaya modal yang harus ditanggung perusahaan. Manajer keuangan di dalam operasinya perlu berusaha untuk memenuhi suatu sasaran tertentu mengenai perimbangan antara besarnya hutang dan jumlah modal sendiri yang tercermin dalam struktur modal perusahaan. Dalam mengambil 
keputusan yang berhubungan dengan struktur modal, manajemen yang kekayaannya tidak terdiversifikasi secara baik mungkin cenderung mengambil keputusan yang menguntungkan mereka dan tidak terlalu berisiko. Hal ini dikarenakan pendapat, masa jabatan dan sebagian dari kekayaan mereka hanya tergantung dari perusahaan yang sudah mempekerjakan mereka.

Suatu perusahaan pasti membutuhkan modal untuk melakukan ekspansi (Arianto, 2008). Bagi perusahaan yang mencari keuntungan biasanya mengutamakan keuntungan bagi pemiliknya atau pemegang saham. Pemegang saham dengan membeli saham berarti mengaharapkan return tertentu dengan risiko minimal. Tingginya tingkat return yang diperoleh pemegang saham maka para pemegang saham akan tertarik dan harga saham semakin tinggi, sehingga kesejahteraan pemegang saham akan meningkat, mempertahankan kelangsungan hidup perusahaan dan melakukan pengembangan usahanya. Hal ini dilakukan dengan cara memaksimalkan nilai perusahaan yang berarti memaksimalkan harga saham yaitu dengan memilih struktur modal yang paling tepat dengan cara menyeimbangkan antara penggunaan hutang dan modal sendiri. Persaingan dalam dunia bisnis yang semakin ketat membuat suatu perusahaan terutama perusahaan grosir berusaha untuk meningkatkan nilai perusahaan. Salah satu cara yang dapat dilakukan untuk meningkatkan nilai perusahaan dengan melalui peningkatan kemakmuran kepemilikan atau para pemegang saham. Keberadaan para pemegang saham dan manajemennya sangatlah penting untuk menentukan besarnya keuntungan yang nantinya akan diperoleh. Dalam menghadapi kondisi seperti ini, setiap perusahaan dianjurkan atau dituntut untuk mampu dan pintar melihat dan membaca situasi yang terjadi sehingga dapat melakukan pengelolaan dengan baik agar dapat menjadi lebih unggul dalam persaingan. Kebjjakan struktur modal dipengaruhi secara langsung oleh besar kecilnya ukuran suatu perusahaan. Ukuran perusahaan dianggap mampu mempengaruhi nilai perusahaan. Karena semakin besar ukuran atau skala perusahaan maka akan semakin mudah pula perusahaan memperoleh sumber pendanaan baik yang bersifat internal maupun eksternal. Ukuran perusahaan menggambarkan besar kecinya suatu perusahaan. Ukuran perusahaaan umumnya berpengaruh pada penilaian investor dalam membuat keputusan investasi. Perusahaan besar akan lebih mudah memperoleh modal di pasar modal dibandingkan dengan perusahaan kecil karena perusahaan besar memiliki probabilitas yang lebih besar untuk memenangkan persaingan atau bertahan dalam industri. Perusahaan yang berukuran besar mempunyai berbagai kelebihan dibanding perusahaan berukuran kecil. Pertama adalah ukuran perusahaan dapat menentukan tingkat kemudahan perusahaan memperoleh dana dari pasar modal. Kedua, ukuran perusahaan menentukan kekuatan tawar-menawar (bargaining power) dalam kontrak keuangan. Ketiga, ada kemungkinan pengaruh skala dalam biaya dan return membuat perusahaan yang lebih besar dapat memperoleh lebih banyak laba (Sawir, 2004). Perusahaan dengan ukuran besar memiliki akses lebih besar dan luas untuk mendapat sumber pendanaan dari luar, sehingga untuk memperoleh pinjaman akan menjadi lebih mudah karena dikatakan bahwa perusahaan dengan ukuran besar memiliki kesempatan lebih besar untuk memenangkan persaingan atau bertahan dalam industry (Sugiono \& Christiawan, 2013).

Tingkat profitabilitas suatu perusahaan menjadi salah satu faktor yang dipertimbangkan dalam kebijakan struktur modal. Brigham dan Gapenski dalam (Sartono, 2001) mengatakan seringkali perusahaan dengan tingkat pengembalian yang tinggi cenderung menggunakan hutang. Tetapi perusahaan dengan tingkat pengembalian yang rendah cenderung menggunakan hutang yang besar untuk membiayai aktivitas perusahaan. Penelitian terdahulu yang menghubungkan profitabilitas terhadap kebijakan struktur modal yang dilakukan oleh Hendri \& Sutapa (2006) menunjukkan bahwa profitabilitas berpengaruh negatif dan signifikan terhadap struktur modal. Tetapi hasil ini bertentangan dengan hasil penelitian yang dilakukan oleh Yuke \& Handri (2005) yang menyatakan bahwa profitabilitas berpengaruh positif dan signifikan terhadap struktur modal. Kepemilikan manajerial merupakan pemisahan kepemilikan antara 
pihak outsider dengan pihak insider. Jika dalam suatu perusahaan memiliki banyak pemilik saham, maka kelompok besar individu tersebut sudah jelas tidak dapat berpartisipasi dengan aktif dalam manajemen perusahaan sehari-hari. Karenanya, mereka memilih dewan komisaris, yang memilih dan mengawasi manajemen perusahaan. Struktur ini berarti bahwa pemilik berbeda dengan manajer perusahaan. Hal ini memberikan stabilitas bagi perusahaan yang tidak dimiliki oleh perusahaan dengan pemilik merangkap manajer. Pertumbuhan penjualan mencerminkan prospek perusahaan dengan horison waktu yang lebih panjang dari profitabilitas tetapi lebih pendek dari pertumbuhan total aktiva (Kaaro, 2003). Perusahaan yang memiliki tingkat pertumbuhan penjualan yang besar akan membutuhkan penambahan aset untuk mendukung pertumbuhan penjualan sehingga perusahaan yang memiliki pertumbuhan penjualan yang besar menggunakan hutang yang lebih banyak. Perusahaan yang memiliki pertumbuhan penjualan yang tinggi dalam periode waktu yang relatif cepat tentu akan bernilai lebih dalam pandangan kreditor dan investor. Hal ini dikarenakan dengan adanya pertumbuhan penjualan yang baik, maka akan berdampak pada keuntungan yang perusahaan dapatkan juga akan baik, sehingga dapat menjamin keberadaan dan keberlangsungan aktivitas perusahaan. Seorang investor yang cerdas akan menghindari saham dengan PER tinggi, apalagi saham itu mempunyai volatilitas yang tinggi sehingga memiliki potensi risiko yang tinggi pula. Nilai perusahaan merupakan harga yang bersedia dibayar oleh calon pembeli apabila perusahaan tersebut djual. Manajer keuangan harus memperhatikan dampak perubahan pada kombinasi modal, hal ini penting karena berpengaruh pada persepsi investor terhadap tingkat resiko dalam menginvestasikan dananya.

\section{Struktur Modal}

Menurut Bambang Riyanto (2004), bahwa sumber dana yang dapat diperoleh untuk membelanjai suatu perusahaan dapat dibedakan menjadi sumber dana dari dalam perusahaan dan sumber dana dari luar perusahaan. Sumber dana dari dalam perusahaan (internal source) dapat diartikan sebagai bentuk dana dimana pemenuhan kebutuhan dananya berasal dari dalam perusahaan itu sendiri, dengan kata lain dana dengan kekuatan atau kemampuan sendiri. Sedangkan sumber dana dari luar perusahaan (externalsource) adalah pemenuhan kebutuhan dana diambil atau berasal dari sumber-sumber dana yang ada di luar perusahaan. Struktur modal adalah topik utama yang terdapat dalam keuangan, baik dibahas sebagai sub topic dalam keuangan perusahaan maupun dalam keputusan investasi. Menurut Van Horne \& Wachowicz (2007), struktur modal adalah bauran (proporsi) pendanaan permanen jangka panjang perusahaan yang dituangkan dalam hutang, ekuitas saham preferen dan saham biasa. Rasio struktur Modal adalah Debt Equity Ratio (DER), Debt to Equity Ratio (DER) adalah rasio keuangan utama dan digunakan untuk menilai posisi keuangan suatu perusahaan. Rasio ini juga merupakan ukuran kemampuan perusahaan untuk melunasi kewajibannya. Rasio Debt to Equity Ratio ini merupakan rasio penting untuk diperhatikan pada saat memeriksa kesehatan keuangan perusahaan. Jika rasionya meningkat, ini artinya perusahaan dibiayai oleh kreditor (pemberi hutang) dan bukan dari sumber keuangannya sendiri yang mungkin merupakan trend yang cukup berbahaya. Rumus untuk menghitung struktur modal menggunakan Debt Equity Ratio sebagai berikut :

DER $=\frac{\text { TotalDebt }}{\text { TotalEquity }} \times 100 \%$

\section{Faktor-Faktor Yang Mempengaruhi Struktur Modal \\ Ukuran Perusahaan (Size) \\ Brigham \& Houston (2001)}

mendefinsikan bahwa ukuran perusahaan merupakan ukuran besar kecilnya sebuah perusahaan yang ditunjukan atau dinilai oleh total asset, total penjualan, jumlah laba, beban pajak dan lain-lain. Dalam hal ini penjualan lebih besar dari pada biaya variabel dan biaya tetap, maka akan diperoleh jumlah pendapatan sebelum pajak. Sebaliknya jika penjualan lebih kecil daripada biaya variabel dan biaya tetap maka perusahaan akan menderita kerugian. Jika perusahaan memiliki total aset yang besar, pihak manajemen lebih leluasa dalam mempergunakan aset yang ada diperusahaan 
tersebut. Jumlah aset yang besar akan menurunkan nilai perusahaan jika dilihat dari sisi pemilik perusahaan. Akan tetapi jika dilihat dari sisi manajemen kemudahan yang dimilikinya dalam mengendalikan perusahaan akan meningkatkan nilai perusahaan (Suherli \& Harahap, 2007). Ukuran perusahaan pada dasarnya adalah pengelompokan perusahaan kedalam beberapa kelompok, di antaranya perusahaan besar, sedang dan kecil. Skala perusahaan merupakan ukuran yang dipakai untuk mencerminkan besar kecilnya perusahaan yang didasarkan kepada total aset perusahaan (Suwito \& Herawaty, 2005). Rumus ukuran perusahaan menggunakan logaritma natural total aset (total assets) adalah sebagai berikut:

\section{Ukuran Perusahaan $=$ Ln Total Assets}

\section{Profitabilitas (ROE)}

ROE (Return on equity) adalah rasio profitabilitas yang mengukur kemampuan perusahaan untuk menghasilkan laba dari investasi pemegang saham di perusahaan tersebut. Dengan kata lain, ROE ini menunjukkan seberapa banyak keuntungan yang dapat dihasilkan oleh perusahaan dari setiap satu rupiah yang dinvestasikan oleh para pemegang saham. Rumus yang digunakan untuk profitabilitas adalah return on equity (ROE) adalah sebagai berikut:

$\mathrm{ROE}=\frac{\text { Earning After Tax (EAT) }}{\text { Total Equity }} \times 100 \%$

\section{Aktivitas}

Rasio aktivitas adalah rasio yang digunakan untuk mengukur efektivitas perusahaan dalam menggunakan aktiva yang dimilikinya (Nugrahani \& Sampurno, 2012). Rasio aktivitas yang digunakan untuk mengukur sampai seberapa besar efektivitas perusahaan dalam menggunakan sumber daya yang berupa aset (Eugene $F$ Brigham \& Houston, 2010). Rumus Aktivitas menggunakan sebagai Turn Asset Turn Over berikut :

TATO $=\frac{\text { Total Sales }}{\text { Total Asset }}$

\section{Struktur Kepemilikan Saham}

Struktur kepemilikan merupakan jenis institusi atau perusahaan yang memegang saham terbesar dalam suatu perusahaan
(Wahyudi \& Pawestri, 2006). Struktur kepemilikan merupakan bahwa semakin besar proporsi kepemilikan manajemen pada perusahaan akan dapat menyatukan kepentingan antara manajer dengan pemegang saham (Jensen, 1986). Rumus Kepemilikan Saham Manajerial sebagai berikut :

Kepemilikan Saham manajerial

$=\frac{\text { Jumlah Saham Pihak Manajerial }}{\text { Total Saham beredar }}$

\section{Pertumbuhan Penjualan}

Pertumbuhan penjualan adalah ukuran mengenai besarnya pendapatan per saham perusahaan yang diperbesar oleh leverage (Weston \& Thomas, 1997). Perusahaan yang memiliki tingkat pertumbuhan penjualan yang tinggi akan membutuhkan lebih banyak investasi pada berbagai elemen aset, baik aset tetap maupun aset lancar. Tingkat pertumbuhan penjualan diwaktu yang akan datang merupakan ukuran sejauh mana laba per lembar saham bisa diperoleh dari pembiayaan permanen yang terdiri dari hutang jangka panjang, saham preferen dan modal pemegang saham (Weston \& Thomas, 1997). Pertumbuhan penjualan mencerminkan prospek perusahaan dengan horison waktu yang lebih panjang dari profitabilitas tetapi lebih pendek dari pertumbuhan total aktiva (Kaaro, 2003) . Perusahaan yang memiliki tingkat pertumbuhan penjualan yang besar akan membutuhkan penambahan aset untuk mendukung pertumbuhan penjualan sehingga perusahaan yang memiliki pertumbuhan penjualan yang besar menggunakan hutang yang lebih banyak. Perusahaan yang memiliki pertumbuhan penjualan yang tinggi dalam periode waktu yang relatif cepat tentu akan bernilai lebih dalam pandangan kreditor dan investor. Hal ini dikarenakan dengan adanya pertumbuhan penjualan yang baik, maka akan berdampak pada keuntungan yang perusahaan dapatkan juga akan baik, sehingga dapat menjamin keberadaan dan keberlangsungan aktivitas perusahaan. Rumus Pertumbuhan Penjualan sebagai berikut :

Pertumbuhan Penjualan

\section{Nilai Perusahaan}

$$
=\frac{\text { netsalest }}{\text { netsalest }-1} \times 100 \%
$$

Menurut Gitman (2000), nilai perusahaan adalah nilai aktual per lembar saham yang akan 
diterima apabila aset perusahaan dïual sesuai harga saham. Pengeluaran investasi memberikan sinyal positif dari investasi kepada manajer tentang pertumbuhan perusahaan di masa yang akan datang, sehingga meningkatkan harga saham sebagai indikator nilai perusahaan. Harga saham yang tinggi membuat nilai perusahaan juga tinggi (Brealey, Myers, \& Marcus, 2007). Rumus Nilai Perusahaan sebagai berikut :

Price to Earning Ratio $=$ Market Price Per Share Earning Per Share

\section{Pengembangan Hipotesis}

\section{Hubungan antara Ukuran Perusahaan} (Size) Dengan Struktur Modal

Perusahaan yang berukuran besar biasanya memiliki arus kas yang stabil (Azomaia, 2014). Oleh karena itu, perusahaan dengan ukuran yang besar akan memiliki tingkat resiko yang lebih rendah dan memiliki akses yang lebih mudah dalam memperoleh hutang. Menurut Daskalaktis \& Psillaki (2005) ukuran perusahaan memiliki pengaruh yang positif terhadap struktur modal. Ukuran Perusahaan mempunyai hubungan dengan risiko kebangkrutan, sebab risiko yang dimiliki perusahaan besar akan lebih kecil. Oleh karena itu perusahaan dengan ukuran yang besar tentu akan dengan mudah dalam memperoleh hutang dari pihak pemberi pinjaman karena kegiatan operasional perusahaan sudah berjalan dengan stabil atau mungkin cenderung semakin berkembang (Titman \& Wessels, 1988). Ukuran yang dimiliki perusahaan menandakan bagaimana kesempatan yang dimiliki perusahaan untuk memperoleh dana. Semakin besar ukurannya, maka perusahaan semakin leluasa dan memiliki kesempatan yang banyak untuk memperoleh dana. Tidak menutup kemungkinan bahwa ukuran yang kecil juga dapat memperoleh sumber dana yang mudah melihat sifat perusahaan kecil lebih fleksibel dan tidak mengeluarkan banyak biaya seperti biaya tenaga kerja dan peralatan. Namun dengan ukuran yang kecil apakah kinerja dapat mencapai titik keefektifan dan keefisiensian. Perusahaan yang memiliki ukuran (Firm Sże) yang besar akan lebih banyak menggunakan hutang daripada perusahaan kecil, karena perusahaan yang lebih besar akan lebih mudah memperoleh pinjaman dibandingkan perusahaan kecil sebab perusahaan yang lebih besar cenderung memiliki tingkat leverage yang lebih tinggi dibandingkan dengan perusahaan kecil, dimana tingkat kebangkrutannya lebih rendah dibandingkan dengan perusahaan kecil sehingga struktur modal juga akan meningkat dikarenakan tingginya hutang.

$\mathrm{H}_{1}$ : Ukuran Perusahaan (sże) mempunyai pengaruh positif terhadap struktur modal.

\section{Hubungan antara Profitabilitas Dengan Struktur Modal}

Menurut pecking order theory, perusahaan dengan tingkat keuntungan yang besar memiliki sumber pendanaan internal yang lebih besar dan memiliki kebutuhan untuk melakukan pembiayaan investasi melalui pendanaan eksternal yang lebih kecil (Schoubben \& Van Hulle, 2004).Dengan demikian, teori ini memprediksikan profitabilitas berpengaruh negatif terhadap struktur modal. Perusahaan dengan rate of return yang tinggi cenderung menggunakan proporsi utang yang relatif kecil. Karena dengan rate of return yang tinggi, kebutuhan dana dapat diperoleh dari laba ditahan. Perusahaan yang profitabilitasnya tinggi akan lebih banyak mempunyai dana internal daripada perusahaan yang profitabilitasnya rendah. Apabila dalam komposisi struktur modal penggunaan modal sendiri lebih besar dari pada penggunaan utang, maka rasio struktur modal akan semakin kecil. Profitabilitas dihitung dari laba dibagi investasi modal (Wild, Subramanyam, \& Halsey, 2005). Perusahaan dengan tingkat pengembalian yang tinggi atas investasi menggunakan hutang yang relatif kecil. Tingkat pengembalian yang tinggi memungkinkan untuk membiayai sebagian besar kebutuhan pendanaan dengan dana yang dihasilkan secara internal. Semakin tinggi profitabilitas maka perusahaan memiliki sumber dana dari dalam yang cukup besar sehingga perusahaan lebih sedikit memerlukan hutang. Selain itu, apabila laba ditahan bertambah, rasio hutang dengan sendirinya akan menurun, dengan asumsi bahwa perusahaan tidak menambah jumlah hutang. Menurut Brigham (2001), profitabilitas merupakan sekelompok rasio yang memperlihatkan pengaruh gabungan 
dari likuiditas, manajemen aktiva dan hutang terhadap hasil operasi.

$\mathrm{H}_{2}$ : Profitabilitas berpengaruh negatif terhadap struktur modal.

\section{Hubungan antara Aktivitas Dengan Struktur Modal}

Semakin tinggi aktivitas perusahaan maka akan semakin efektif pihak manajemen dalam mengelola aset perusahaan untuk menjalankan kegiatan perusahaan. Aktivitas perusahaan yang dihitung dengan perputaran aset merupakan analisis yang dilakukan terhadap tingkat profitabilitas perusahaan yang lebih difokuskan untuk menilai efektifitas perusahaan dan intensitas aset dalam menghasilkan penjualan. Semakin tinggi nilai perputaran aset mencerminkan semakin tinggi pula nilai penjualan tehadap nilai total aset. Hal ini sesuai dengan yang dikemukakan oleh Subramanyam \& Wild (2010) bahwa perputaran aset merupakan cara perusahaan dalam memanfaatkan aset perusahaan yang dapat diukur melalui perbandingan antara penjualan dengan total aset. Bukti empiris dari hasil penelitian Gunawan (2013) menunjukkan bahwa perputaran aset berpengaruh terhadap struktur modal. Selain itu hasil penelitian ini sesuai dengan Riyanto (2001) yang menyatakan bahwa keadaan aset yang tinggi atau rendah akan memberikan gambaran tentang perputaran aset dan keuntungan yang dapat dicapai perusahaan dari perputaran aset tersebut. Suatu aset yang tinggi akan memberikan gambaran tingkat solvabilitas yang tinggi sehingga risiko perusahaan akan semakin rendah dalam melunasi hutang-hutang perusahaan.

$\mathrm{H}_{3}$ : Aktivitas mempunyai pengaruh positif terhadap struktur modal.

\section{Hubungan antara Struktur Kepemilikan} Saham Manajerial Dengan Struktur Modal Hasil penelitian Rahadian (2014) menyatakan bahwa kepemilikan manajerial berpengaruh positif dan signifikan terhadap struktur modal. Tindakan manajer yang merupakan bagian dari struktur kepemilikan akan berdampak terhadap keputusan pendanaan, apakah perusahaan akan meningkatkan nilai perusahaan dengan mengambil dana dari luar perusahaan atau dari dalam perusahaan. Dengan kata lain keputusan pendanaan melibatkan para pemilik saham perusahaan yang merupakan bagian dari struktur kepemilikan. Penelitian yang dilakukan oleh Braislsforda et al. (1999) bahwa struktur kepemilikan dan struktur modal mempunyai hubungan yang positif signifikan. Teori agen mempunyai pengaruh yang cukup besar terhadap para pemegang saham atau kepemilikan saham sehingga berdampak pada keputusan pendanaan dari suatu perusahaan (struktur modal). Hasil penelitian Huang \& Frank (2002), meneliti faktor-faktor dari stuktur modal studi kasus dari fakta-fakta yang ada di China menemukan bahwa pajak, ukuran perusahaan, aktiva tetap dan struktur kepemilikan mempunyai pengaruh positif signifikan terhadap struktur modal. Adanya kepemilikan manajerial dalam perusahaan merupakan satu cara yang tepat, karena dengan seperti ini para manajer diberikan kesempatan untuk memiliki saham dalam perusahaan yang dikelolanya, dan mempunyai kepentingan yang sama pula dengan para pemegang saham lainnya. Dengan adanya kepemilikan manajerial diharapkan para manajer akan termotivasi untuk meningkatkan kinerjanya sehingga nantinya dapat meningkatkan nilai perusahaan yang otomatis akan meningkatkan kesejahteraan pemilik saham dari perusahaan tersebut.

$\mathrm{H}_{4}$ : Struktur Kepemilikan Saham Manajerial berpengaruh positif terhadap struktur modal perusahaan.

\section{Hubungan Pertumbuhan Penjualan Dengan Struktur Modal}

Menurut Brigham \& Houston (2011), perusahaan dengan tingkat penjualan yang relatif stabil dapat lebih aman memperoleh banyak pinjaman dan menanggung beban tetap yang lebih tinggi dibandingkan dengan perusahaan yang penjualannya tidak stabil. Jadi perusahaan yang penjualan atau tingkat pertumbuhannya tinggi lebih cenderung menggunakan hutang lebih besar daripada perusahaan yang tingkat pertumbuhannya tidak stabil. Pertumbuhan perusahaan (Growth) yang tinggi mengindikasikan bahwa perusahaan cenderung mengunakan utang yang kecil. Terdapat dua sinyal pertumbuhan perusahaan berdasarkan hipotesis pecking order theory, 
yaitu sinyal positif dan sinyal negatif. Sinyal negatif dimana perusahaan dengan tingkat pertumbuhan yang tinggi akan cenderung menjaga dan mempertahankan rasio utang pada level yang rendah. Sinyal positif adalah sinyal dimana perusahaan dengan tingkat pertumbuhan tinggi akan melakukan ekspansi dengan cara menggunakan utang. Perusahaan dengan pertumbuhan penjualan yang stabil dapat lebih aman, lebih banyak pinjaman dan lebih mampu menanggung beban yang lebih tinggi dibandingkan dengan perusahaan yang pertumbuhan penjualannya tidak stabil. Tingkat pertumbuhan penjualan merupakan ukuran sampai sejauh mana penjualan perusahaan dapat ditingkatkan, sehingga semakin tinggi peningkatan penjualan, maka akan semakin tinggi pula struktur modal perusahaan.

$\mathrm{H}_{5}$ : Pertumbuhan Penjualan berpengaruh positif terhadap struktur modal perusahaan.

\section{Hubungan Struktur Modal terhadap Nilai Perusahaan}

Berdasarkan penelitian Fernandes Moniaga (2013) ditemukan bahwa struktur modal berpengaruh terhadap nilai perusahaan. Teori trade-off dari kverage adalah teori yang menjelaskan bahwa struktur modal yang optimal ditemukan dengan menyeimbangkan manfaat dari pendanaan dengan hutang (perlakukan pajak perseroan yang menguntungkan) dengan suku bunga dan kebangkrutan yang lebih tinggi (Brigham \& Houston, 2001). Sebaliknya, jika posisi struktur modal berada diatas titik optimal maka setiap penambahan hutang akan menurunkan nilai perusahaan. Oleh karena itu, dengan asumsi titik target struktur modal optimal belum tercapai, maka berdasarkan trade-off theory memprediksi adanya hubungan yang positif terhadap nilai perusahaan. Hasnawati (2005) dalam penelitiannya menunjukan bahwa keputusan pendanaan berpengaruh positif terhadap nilai perusahaan. Pada dasarnya struktur modal yang meningkat cenderung akan meningkatkan nilai perusahaan karena menunjukkan tingkat modal perusahaan yang tinggi dalam meningkatkan keuntungan.

H6: Hubungan Struktur Modal berpengaruh positif terhadap nilai perusahaan.

\section{Metode Penelitian}

Penelitian ini merupakan penelitian kausalitas. Data yang dipakai dalam penelitian ini adalah data sekunder. Data sekunder yang dipergunakan dalam penelitian ini adalah data laporan keuangan pada perusahaan wholesaler dan retail yang terdaftar di Bursa Efek Indonesia (BEI). Data yang digunakan dalam penelitian ini adalah data panel yang terdiri dari data perusahaan Wholesaler dan Retail pada periode 2013-2017. Disamping itu, penelitian ini menggunakan teknik pengambilan sampel penelitian secara purposive sampling yaitu teknik pengambilan sampel dengan menggunakan kriteria yang ditentukan oleh peneliti. Adapun kriteria pengambilan sampel yang digunakan: perusahaan tersebut memiliki laporan keuangan tahunan periode 2013 sampai dengan 2017 dan perusahaan mempunyai data lengkap untuk semua variabel yang diperlukan untuk mendukung penelitian ini. Dalam penelitian ini terdapat dua fungsi variabel yaitu variabel dependen dan variabel independen. Ukuran perusahaan (sże), profitabilitas, aktivitas, struktur kepemilikan saham dan pertumbuhan penjualan, nilai perusahaan berfungsi sebagai variabel independen. Yang berfungsi sebagai variabel dependen ( $Y$ ) adalah struktur modal. Model regresi linier berganda dapat dicapai bila memenuhi asumsi klasik. Pengujian asumsi klasik meliputi uji normalitas, uji autokorelasi, uji multikolinieritas dan uji heteroskedastisitas. Namun menurut Gujarati (2004) menyatakan bahwa uji normalitas tidak disyaratkan bagi penelitian ukuran sampel yang besar. Penelitian ini hanya melakukan tiga uji asumsi klasik yaitu uji autokorelasi, uji multikolinieritas dan uji heterokedastisitas. Uji Autokorelasi bertujuan mengetahui apakah terjadi korelasi antara variabel error pada periode $t$ dan periode $t-1$ dalam model regresi. Untuk mendeteksi adanya autokorelasi model regresi linier berganda dilakukan Durbin Watson (DW). Nilai statistik DW akan bernilai dua jika tidak terdapat autokorelasi, bernilai nol jika terdapat autokorelasi positif dan bernilai empat jika terdapat autokorelasi negatif. Uji Multikolinearitas bertujuan untuk mengetahui apakah dalam model regresi ditemukan adanya korelasi antar variabel bebas atau tidak, model yang baik seharusnya tidak terjadi korelasi yang tinggi diantara variabel bebas. Cara untuk 
mendeteksi adanya multikolinearitas dilakukan dengan cara mendeteksi high-pair wise correlation among regressors, melalui $\mathrm{R}^{2}$ yang tinggi dalam model tetapi tingkat signifikansi tstatistiknya sangat kecil dari hasil regresi tersebut dan cenderung banyak yang tidak signifikan. Uji Heterokedastisitas bertujuan mengetahui apakah dalam model regresi terdapat ketidaksamaan varians variabel pengganggu antara pengamatan satu ke pengamatan lain. Untuk menciptakan regresi yang baik, maka dalam model regresi tidak boleh terdapat heteroskedastisitas atau harus bersifat homokedastisitas. Pengujian statistik diharapkan dapat menghilangkan unsur bias tersebut. Uji statistik yang dipergunakan adalah Uji Glejser, yang dilakukan dengan meregresikan variabel-variabel bebas terhadap nilai absolut residualnya. Residual adalah selisih antar nilai observasi dengan nilai prediksi dan absolut adalah nilai mutlaknya.

Penelitian ini dilakukan dengan menggunakan model regresi logistik karena model variabel dependen dalam model adalah variabel kategori (dikotomi variable), dengan memberi nilai 1 untuk perusahaan yang memiliki hutang tinggi dan nilai 0 untuk perusahaan yang tidak memiliki hutang tinggi. Uji beda Anova merupakan singkatan dari "analysis of varian". Analysis of Varian adalah salah satu uji komparatif yang digunakan untuk menguji perbedaan mean (rata-rata) data lebih dari dua kelompok. Analisis of variance atau
ANOVA merupakan salah satu teknik analisis multivariate yang berfungsi untuk membedakan rerata lebih dari dua kelompok data dengan cara membandingkan variansinya

\section{Hasil dan Pembahasan Uji Asumsi Klasik}

Uji Normalitas dapat dilihat pada Jerque-Bera dan Probability. Jika Probability >a maka data terdistribusi normal. Pada Tabel 1 di lampiran, tidak berdistribusi normal karena $0,000000<0,05$. Ada atau tidaknya multikolinearitas dapat dilihat dari nilai koefisien korelasi antar variabel independen. Bila nilai korelasi variabel independen diatas 0,800 maka terjadi multikolinearitas pada variabel tersebut (Ghozali, 2011). Berdasarkan hasil penelitian, terlihat bahwa nilai koefisien korelasi semua variabel independen berada dibawah 0,800. Disimpulkan bahwa tidak terjadi multikolinearitas antar variabel independen. Apabila nilai probabilitas $<0,05$ maka adanya heteroskedastisitas. Sebaliknya apabila nilai probabilitas pada setiap variabel independen > 0,05 maka terbebas dari pelanggaran asumsi heteroskedastis. Hasil Uji Glejser terlihat adanya probabilitas variabel independen $>0,05$ sehingga terbebas dari heterokedastisitas. Uji Autokorelasi dengan uji Breusch-Godfrey Serial Correlation LM Test dapat dilihat nilai Prob Chi Square(2) masing-masing adalah 0,1674 dimana $>0,05$ sehingga terima $\mathrm{H}_{0}$ atau yang berarti tidak ada masalah autokorelasi.

Tabel 1

hasil uji klasik

\begin{tabular}{|c|c|c|}
\hline $\begin{array}{c}\text { Uji Asumsi } \\
\text { Klasik }\end{array}$ & Hasil Uji & Keterangan \\
\hline $\begin{array}{c}\text { Uji } \\
\text { Multikolinearitas }\end{array}$ & $\begin{array}{c}\text { Nilai Koefisien Korelasi } \\
\text { Variabel independen }< \\
0,800\end{array}$ & $\begin{array}{c}\text { Tidak terjadi } \\
\text { Multikolinearitas }\end{array}$ \\
\hline $\begin{array}{c}\text { Uji } \\
\text { Heterokedastisitas }\end{array}$ & $\begin{array}{c}\text { Nilai Koefisien Korelasi } \\
\text { Variabel independen }< \\
0,800\end{array}$ & $\begin{array}{c}\text { Terbebas dari } \\
\text { Heterokedastisitas }\end{array}$ \\
\hline Uji Autokorelasi & $\begin{array}{c}\text { Nilai Prob Chi Square } \\
\text { (2) } 0,1674>0,5\end{array}$ & $\begin{array}{c}\text { Tidak ada masalah } \\
\text { Autokorelasi }\end{array}$ \\
\hline
\end{tabular}

Sumber : Hasil Olah Data

\section{Analisis Statistik Deskripstif}

Berdasarkan hasil penelitian ini, untuk rata-rata perusahaan yang memiliki rata-rata struktur modal yang paling rendah adalah SQMI tahun 2015 sebesar -0,73 yang merupakan perusahaan wholesaler. DER yang negatif dikarenakan equity yang dimiliki oleh SQMI 
tahun 2015 bernilai -73,88 (dalam juta rupiah). Hal ini menunjukkan semakin rendah rasio DER akan semakin baik kemampuan perusahaan dalam membayar kewajiban jangka panjangnya. Sementara itu DER tertinggi dimiliki oleh OKAS pada tahun 2016 sebesar 8,05 yang merupakan perusahaan wholesaler. Hal ini menunjukkan komposisi total hutang (jangka pendek dan jangka panjang) semakin besar dibanding dengan total modal sendiri sehingga berdampak semakin besar beban perusahaan terhadap pihak luar (kreditur). Hal ini mengindikasikan resiko bisnis yang tinggi terutama jika perusahaan berada pada kondisi dilikuidasi maka equity tidak dapat menutupi Debt yang tinggi.

Berdasarkan hasil penelitian ini, untuk rata-rata tahunan perusahaan yang memiliki rata-rata pertumbuhan penjualan yang paling rendah adalah IITG pada tahun 2017, SQMI pada tahun 2017 dan TRIO pada tahun 2015 sebesar $-1,00$ yang merupakan perusahaan wholesaler dan retailer. Tahun 2017, ITTG dan SQMI mengalami penurunan penjualan dari tahun 2016. Tahun 2015, TRIO mengalami penurunan penjualan dari tahun 2014. Hal ini menunjukkan pertumbuhan penjualan rendah maka akan mencerminkan pendapatan perusahaan yang menurun. Sementara itu growth tertinggi dimiliki oleh AIMS pada tahun 2017 sebesar 4,63 yang merupakan perusahaan wholesaler. Hal ini menunjukkan bahwa pertumbuhan penjualan tinggi maka akan meningkatkan pendapatan perusahaan yang akan mempengaruhi kemampuan perusahaan mempertahankan keuntungan.

Berdasarkan hasil penelitian ini, untuk perusahaan yang memiliki ROE yang paling rendah adalah CNKO pada tahun 2017 sebesar $-3,76$ yang merupakan perusahaan wholesaler. $\mathrm{Hal}$ ini menunjukkan tahun 2017, CNKO mengalami kerugian sebesar -3.76 (dalam juta rupiah) dibandingkan dengan ekuitas yang dimiliki perusahaan. ROE tertinggi yang dimiliki oleh LPPF pada tahun 2014 sebesar 7,99 yang merupakan perusahaan retail. $\mathrm{Hal}$ ini menunjukkan semakin besar dana yang dapat dikembalikan dari ekuitas menjadi laba.

Berdasarkan hasil penelitian ini, untuk rata-rata tahunan perusahaan yang memiliki ukuran perusahaan yang paling rendah adalah
ITTG pada tahun 2015 sebesar 18,46 yang merupakan perusahaan wholesaler. $\mathrm{Hal}$ ini menunjukkan ukuran perusahaan dalam pengelolaan aset kurang terkendali. Sże perusahaan tertinggi yang dimiliki oleh UNTR pada tahun 2017 sebesar 32,04 yang merupakan perusahaan wholesaler. Hal ini menunjukkan pencapaian operasional lancar dan pengendalian aset perusahaan terkendali.

Berdasarkan hasil penelitian ini, untuk rata-rata tahunan perusahaan yang dimiliki stuktur kepemilikan manajerial yang paling rendah adalah EPMT, FISH pada tahun 2014 sebesar 0,00 yang merupakan perusahaan wholesaler. UNTR pada tahun 2015 yang merupakan perusahaan wholesaler. Juga GOLD, MAPI pada tahun 2014 yang merupakan perusahaan retail. Struktur Kepemilikan Manajerialyang rendah pada RIMO di tahun 2013, CENT di tahun 2016, dan SONA di tahun 2015 yang merupakan perusahaan retail yang terdaftar di BEI. Hal ini menunjukkan perusahaan semakin rendah proporsi kepemilikan manajemen pada perusahaan, maka manajemen cenderung kurang giat untuk kepentingan pemegang saham yang tidak lain adalah dirinya sendiri. Struktur Kepemilikan Manajerial tertinggi yang dimiliki oleh BMSR pada tahun 2017 sebesar 2,36 yang merupakan perusahaan wholesaler. Hal ini menunjukkan semakin besar proporsi kepemilikan manajemen pada perusahaan, maka manajemen cenderung berusaha lebih giat untuk kepentingan pemegang saham yang tidak lain adalah dirinya sendiri.

Berdasarkan hasil penelitian ini, untuk rata-rata tahunan perusahaan yang memiliki TATO yang paling rendah dari perusahaan wholesaler adalah INTD (tahun 2013), ITTG (tahun 2016-2017), JKON (tahun 2016-20017), MDRN (tahun 2015), SQMI (tahun 2013). Perusahaan yang memiliki TATO yang paling rendah dari perusahaan retail adalah GOLD (tahun 2015), SKYB (tahun 2015-2016). Hal ini menunjukkan penjualan lebih tinggi daripada asset-aset yang dimiliki. Aktivitas perusahaan tertinggi yang dimiliki oleh GLOBpada tahun 2015 sebesar 20,42 yang merupakan perusahaan retail. Hal ini menunjukkan perusahaan mampu menghasilkan penjualan yang lebih tinggi sehingga dapat menaikkan 
nilai perputaran asetnya.

Tabel 2

Ringkasan Penelitian

\begin{tabular}{lcrrrcc}
\hline & DER & GROWTH & \multicolumn{1}{c}{ ROE } & SIZE & \multicolumn{1}{c}{ SKP } & TATO \\
\hline Mean & 0.472046 & 0.123095 & 0.103263 & 27.87472 & 0.696700 & 1.919867 \\
Median & 0.016300 & 0.036207 & 0.077150 & 28.53596 & 0.754468 & 1.454578 \\
Maximum & 8.050000 & 4.630108 & 7.991000 & 32.04093 & 2.363871 & 20.42491 \\
Minimum & -0.738800 & -1.000 .000 & -3.757 .000 & 18.46050 & 0.000000 & 0.000000 \\
Std. Dev. & 1.267027 & 0.575504 & 0.679762 & 2.061125 & 0.259172 & 2.074124 \\
\hline
\end{tabular}

Sumber : Hasil Olah Data

\section{Uji Regresi Logistik}

Hipotesis pengujian yang dilakukan menggunakan uji regresi logistik, yaitu: $\mathrm{H}_{0}$ : Probabiltys 0,05 berarti model mampu memprediksi nilai obsevasinya. $\mathrm{H} 1$ : Probability $<0,05$ berarti model ada perbedaan antara model dengan nilai observasinya sehingga model tidak dapat memprediksi nilai observasinya. Hasil olahan data, menunjukkan bahwa Probability 0,105 $>0,05$ berarti model dapat diterima. Hasil penelitian menunjukkan bahwa model yang terbentuk memprediksi nilai observasi / memiliki tingkat akurasi sebesar $81.8 \%$

\section{Tabel 3}

\section{Ringkasan Penelitian}

\begin{tabular}{|c|c|c|c|c|}
\hline & $B$ & Sig. & Hipotesis & Pengaruh/signifikan \\
\hline SIZE $(H 1)$ & -.210 & .073 & $(+)$ & (-) tidak diterima \\
\hline $\mathrm{ROE}(\mathrm{H} 2)$ & 1.060 & .020* & $(-)$ & (-) di terima \\
\hline TATO (H3) & .104 & .200 & $(+)$ & $(+)$ tidak diterima \\
\hline SKP $(H 4)$ & .586 & .445 & $(+)$ & $(+)$ tidak diterima \\
\hline GROWTH (H5) & 1.036 & $.018^{*}$ & $(+)$ & (-) di terima \\
\hline \multicolumn{4}{|c|}{$\begin{array}{l}\text { Hosmer and Lemeshow Test: } \\
0.105 \text { Overall Percentage : } 81,8\end{array}$} & \\
\hline
\end{tabular}


Analisis Penjelasan

Pengaruh Growth, ROE, Size, Struktur Kepemilikan Manajerial dan TATO Terhadap DER

Dari Tabel 7 di lampiran, menunjukkan bahwa $81,8 \%$ dari varians DER dapat djelaskan oleh perubahan Growth, Sże, ROE, Struktur Kepemilikan Saham dan TATO sedangkan sebesar 18,2\% DER dipengaruhi oleh faktorfaktor lain seperti pada trade off theory yang menyatakan bahwa dalam menentukan struktur modal yang optimal memasukkan beberapa faktor seperti pajak, agency cost, financial distress. Hasil Regresi Logistik menunjukkan faktor penentu perusahaan menggunakan hutang atau modal sendiri yang paling dominan adalah ROE. Dari uji analisa regresi data panel dengan metode Hosmer and Lemeshow Test didapatkan persamaan regresinya sebagai berikut: $\mathrm{DER}=4,038$ - 1,060ROE 1,036GROWTH + c

\section{Pengaruh Pertumbuhan Penjualan (Growth of Sales)Terhadap Struktur Modal (DER)}

Pada Tabel diatas, hasil yang diperoleh dari pengujian regresi tersebut didapatkan nilai koefisien regresi untuk growth $-1,036$ dengan nilai Sig. sebesar 0,018. Hasil regresi Hosmer and Lemeshow Test tidak mendukung hipotesis yang diajukan dalam penelitian ini bahwa pertumbuhan penjualan berpengaruh negatif dan signifikan terhadap struktur modal.

\section{Pengaruh Profitabilitas(ROE) Terhadap Struktur Modal (DER)}

Pada Tabel diatas, hasil yang diperoleh dari pengujian regresi tersebut didapatkan nilai koefisien regresi untuk ROE $-1,06$ dengan nilai Sig. sebesar 0,02. Hasil regresi Hosmer and Lemeshow Test menerima hipotesis yang mengatakan ukuran perusahaan berpengaruh negatif dan signifikan terhadap struktur modal.

\section{Pengaruh Size (Ln Total Asset) Perusahaan Terhadap Struktur Modal (DER)}

Pada Tabel diatas, hasil yang diperoleh dari pengujian regresi tersebut didapatkan nilai koefisien regresi untuk Sże -0,21 dengan nilai Sig. sebesar 0,073. Hasil regresi Hosmer and Lemeshow Test tidak menerima hipotesis yang mengatakan ukuran perusahaan berpengaruh negatif dan tidak signifikan terhadap struktur modal.

\section{Pengaruh Struktur Kepemilikan Manajerial Terhadap Struktur Modal (DER)}

Pada Tabel diatas, hasil yang diperoleh dari pengujian regresi tersebut didapatkan nilai koefisien regresi untuk Struktur Kepemilikan Saham 0,586 dengan nilai Sig. sebesar 0,445. Hasil regresi Hosmer and Lemeshow Test mendukung hipotesis yang mengatakan Struktur Kepemilikan Saham berpengaruh positif dan tidak signifikan terhadap struktur modal.

\section{Pengaruh Aktivitas Perusahaan Terhadap Struktur Modal (DER)}

Pada Tabel diatas, hasil yang diperoleh dari pengujian regresi tersebut didapatkan nilai koefisien regresi untuk Aktivitas Perusahaan 0,104 dengan nilai Sig. sebesar 0,2. Hasil regresi Hosmer and Lemeshow Test mendukung hipotesis yang mengatakan Aktivitas Perusahaan berpengaruh positif dan tidak signifikan terhadap struktur modal.

\section{Uji Beda}

Uji Beda menggunakan Uji Anova. Uji Anova adalah salah satu uji komparatif yang digunakan untuk menguji perbedaan mean (rata-rata) data lebih dari dua kelompok. Berdasarkan hasil penelitian ini, nilai Sig 0,866 yang artinya lebih besar dari 0,05

\section{Diskusi}

Hasil regresi Hosmer and Lemeshow Test tidak mendukung dengan penelitian Brigham \& Houston (2011), perusahaan dengan tingkat penjualan yang relatif stabil dapat lebih aman memperoleh banyak pinjaman dan menanggung beban tetap yang lebih tinggi dibandingkan dengan perusahaan yang penjualannya tidak stabil. Perusahaan dengan tingkat pertumbuhannya tinggi lebih cenderung menggunakan hutang lebih besar daripada perusahaan yang tingkat pertumbuhannya tidak stabil. Hasil penelitian ini menunjukkan pertumbuhan penjualan berpengaruh negatif terhadap struktur modal. Penelitian ini mengindikasikan bahwa tingkat pertumbuhan 
yang tinggi akan mengurangi penggunaan hutang. Perusahaan dengan pertumbuhan penjualan yang stabil tidak lebih aman, tidak mampu menanggung beban yang lebih tinggi dibandingkan dengan perusahaan yang pertumbuhan penjualannya tidak stabil. Perusahaan lebih mengandalkan penggunaan ekuitas (modal sendiri) dengan pertumbuhan perusahaan yang meningkat. Hasil penelitian menunjukkan mendukung penelitian Schoubben \& Van Hulle (2004) bahwa profitabilitas berpengaruh negatif terhadap struktur modal. Penelitian Wild \& Halsey (2005), perusahaan dengan tingkat pengembalian yang tinggi atas investasi menggunakan hutang yang relatif kecil. Tingkat pengembalian yang tinggi memungkinkan untuk membiayai sebagian besar kebutuhan pendanaan dengan dana yang dihasilkan secara internal. Semakin tinggi profitabilitas maka perusahaan memiliki sumber dana dari dalam yang cukup besar sehingga perusahaan lebih sedikit memerlukan hutang. Selain itu, apabila laba ditahan bertambah, rasio hutang dengan sendirinya akan menurun.

Hasil penelitian menunjukkan ukuran perusahaan tidak berpengaruh positif terhadap struktur modal. Hasil penelitian tidak mendukung dengan penelitian Daskalaktis \& Psillaki (2005) ukuran perusahaan memiliki pengaruh yang positif terhadap struktur modal. Hasil penelitian ini menunjukkan ukuran perusahaan yang besar belum tentu akan dengan mudah dalam memperoleh hutang dari pihak pemberi pinjaman karena kegiatan operasional perusahaan sudah berjalan dengan stabil atau mungkin cenderung semakin berkembang. Bagi pihak perusahaan yang memiliki sże tinggi sangat berpengaruh besar dalam hal memperoleh modal dari eksternal. Sehingga dengan pinjaman modal dapat mendukung dalam hal operasional perusahaan dan menyebabkan produktivitas perusahaan meningkat sehingga profitabilitas perusahaan meningkat. Sże perusahaan yang cukup besar menunjukkan bahwa perusahaan berada di posisi mature. Namun hasil penelitian ini menunjukkan size tinggi namun growth rendah. Pada tahap mature, perusahaan digambarkan seperti orang dewasa. Perusahaan memasuki tahap dimana para manajernya mulai professional. Tetapi umur perusahaan tidak panjang lagi dan mengarah pada tahap akhir dalam life cycle perusahaan. Ada beberapa perusahaan yang tetap berada pada tahap ini untuk jangka waktu yang panjang tapi ada juga yang mengarah pada kebangkrutan. Pada tahap setelah mature, ada perusahaan yang tidak memasuki tahap decline tetapi tetap berada pada posisi yang stabil.

Hasil penelitian menunjukkan tidak mendukung penelitian Rahadian (2014) menyatakan bahwa kepemilikan manajerial berpengaruh positif dan signifikan terhadap struktur modal. Tindakan manajer yang merupakan bagian dari struktur kepemilikan akan berdampak terhadap keputusan pendanaan, apakah perusahaan akan meningkatkan nilai perusahaan dengan mengambil dana dari luar perusahaan atau dari dalam perusahaan. Penelitian ini tidak mendukung penelitian yang dilakukan oleh Braislsforda et al. (1999) bahwa struktur kepemilikan dan struktur modal mempunyai hubungan yang positif signifikan. Hasil penelitian tidak mendukung penelitian Huang \& Frank (2002), meneliti faktor-faktor dari stuktur modal studi kasus dari fakta-fakta yang ada di China menemukan bahwa pajak, ukuran perusahaan, aktiva tetap dan struktur kepemilikan mempunyai pengaruh positif signifikan terhadap struktur modal. Adanya kepemilikan manajerial dalam perusahaan merupakan satu cara yang tepat, karena dengan seperti ini para manajer diberikan kesempatan untuk memiliki saham dalam perusahaan yang dikelolanya, dan mempunyai kepentingan yang sama pula dengan para pemegang saham lainnya. Dengan adanya kepemilikan manajerial diharapkan para manajer akan termotivasi untuk meningkatkan kinerjanya sehingga nantinya dapat meningkatkan nilai perusahaan yang otomatis akan meningkatkan kesejahteraan pemilik saham dari perusahaan tersebut.

Hasil penelitian menunjukkan aktivitas perusahaan berpengaruh positif terhadap struktur modal sama dengan hipotesis. Hal ini tidak sesuai dengan yang dikemukakan oleh Subramanyam \& Wild (2010) bahwa perputaran aset merupakan cara perusahaan dalam memanfaatkan aset perusahaan yang dapat diukur melalui perbandingan antara penjualan dengan total aset. Bukti empiris dari hasil penelitian Gunawan (2013) menunjukkan 
bahwa perputaran aset berpengaruh terhadap struktur modal. Selain itu hasil penelitian ini tidak sesuai dengan Riyanto (2001) yang menyatakan bahwa keadaan aset yang tinggi atau rendah akan memberikan gambaran tentang perputaran aset dan keuntungan yang dapat dicapai perusahaan dari perputaran aset tersebut. Suatu aset yang tinggi akan memberikan gambaran tingkat solvabilitas yang tinggi sehingga risiko perusahaan akan semakin rendah dalam melunasi hutang-hutang perusahaan.

Hasil uji beda Anova tidak terdapat perbedaan nilai perusahaan antara perusahaan yang menggunakan hutang tinggi atau hutang rendah. Hasil penelitian menguatkan teori Modigliani Miller. Bahwa keputusan hutang tidak berpengaruh terhadap nilai perusahaan sehingga tidak ada perbedaan nilai antara perusahaan yang tidak didanai hutang dan perusahaan yang di danai hutang.

Perusahaan yang memiliki pertumbuhan usaha yang semakin meningkat akan cenderung mengurangi proporsi hutang dalam struktur modal, hal ini ditujukan agar perusahaan terhindar dari kewajiban yang muncul atas perusahaan sehingga perusahaan dapat berkonsentrasi pada pengembangan bisnis. Untuk mengatasi pertumbuhan penjualan yang turun dapat dilakukan dalam hal pemasaran dengan cara mempromosikan produk kepada pelanggan. Strategi pemasaran untuk meningkatkan penjualan dan loyalitas pelanggan sehingga akan meningkatkan pendapatan dalam perusahaan. Perusahaan juga akan melakukan inovasi produk sehingga dapat membedakan produk perusahaan dengan perusahaan lain sejenis. Perusahaan wholesaler yang memiliki profitabilitas yang meningkat akan mengurangi pendanaan hutang supaya terhindar dari kondisi kesulitan keuangan. Profitabilitas yang diperoleh digunakan sebagai sumber dana untuk melakukan inovasi. Inovasi diperlukan untuk bisa mempertahankan hidup dan memenangkan persaingan yang semakin ketat.

\section{Kesimpulan}

Berdasarkan hasil analisis data dan pembahasan yang telah dikemukakan maka dapat diambil kesimpulan: (1) Hasil penelitian ini menunjukkan pertumbuhan penjualan berpengaruh negatif terhadap struktur modal. Penelitian ini mengindikasikan bahwa tingkat pertumbuhan yang tinggi akan mengurangi penggunaan hutang. ; (2) Dari hasil penelitian ini profitabilitas (ROE) berpengaruh negatif terhadap struktur modal mengindikasikan bahwa perusahaan yang memiliki profitabilitas meningkat akan mengurangi pendanaan hutang, profit akan digunakan sebagai dana untuk terus melakukan inovasi. ; (3) Tidak terdapat perbedaan nilai perusahaan yang memiliki pendanaan hutang tinggi dan hutang rendah.

Penelitian ini tidak terlepas dari keterbatasan-keterbatasan. Adapun keterbatasan tesis ini adalah data yang digunakan merupakan data tahunan. Sampel perusahaan yang digunakan dalam penelitian ini hanya 62 perusahaan yang terdaftar di BEI. Lama tahun yang digunakan hanya 5 tahun dari tahun 2013 sampai tahun 2017. Faktor-faktor yang mempengaruhi struktur modal yang digunakan pada penelitian ini hanya menggunakan pertumbuhan penjualan, ukuran perusahaan, profitabilitas (ROE), Struktur Kepemilikan Manajerial dan Aktivitas perusahaan (TATO). Faktor-faktor yang lainnya seperti struktur aktiva, growth opportunity, risiko bisnis, siklus bisnis yang juga mempengaruhi struktur modal. Juga perusahaan yang digunakan hanya pada perusahaan retail dan wholesaler.

Bagi akademis dan peneliti lebih lanjut, dapat memperluas penelitian dengan cara memperpanjang periode penelitian dengan menambah jumlah pengamatan dengan data triwulan, kuartal atau semester. Juga dapat menambah variabel lainnya yang dapat mempengaruhi struktur modal seperti pajak, agency cost, financial distress. Untuk penelitian selanjutnya, peneliti dapat menambah tahun penelitian yang lebih dari lima tahun. Bagi perusahaan atau pemilik dan manajer dapat mempertimbangkan faktor profitabilitas (ROE) dan ukuran perusahaan yang memiliki pengaruh positif terhadap struktur modal sehingga struktur modal yang ditetapkan dapat meningkatkan nilai perusahaan. Bagi investor, dalam memberikan dana pinjaman hendaknya selalu memperhatikan struktur modal dan tingkat ROE yang dapat diperoleh perusahaan serta ukuran perusahaan, jika ukuran 
perusahaan besar maka investor tepat untuk melakukan investasi terhadap perusahaan tersebut, karena perusahaan tersebut memiliki struktur modal tinggi dimana banyak pemodal yang memberikan utang kepada perusahaan tersebut.

\section{Implikasi Manajerial}

Strategi meningkatkan penjualan retail adalah sebagai berikut: (1) Memiliki visualisasi yang menarik dari sebuah toko (retali) sangatlah penting, karena akan membuat banyak konsumen tertarik untuk mampir ke toko; (2) membuat dynamic display adalah dengan membuat tema yang sesuai dengan pada saat itu, misal hari kemerdekaan dengan nuansa merah putih, dan menggunakan motto kemerdekaan untuk membuat selling promonya; (3) menyediakan produk dengan semua varian, semakin lengkap tentunya akan semakin baik, hanya saja semakin lengkap akan semakin sulit pengaturannya, selain membutuhkan biaya yang lebih besar; (4) Karyawan toko atau sales counter memiliki peranan sangat penting dalam meningkatkan omset penjualan retail. Cara meningkatkan penjualan grosir adalah sebagai berikut: (1) mendapatkan lebih banyak pelanggan yang berkualitas dengan cara mengoptimalkan kampanye pemasaran, melakukan follow up melalui telepon dan email, berpartisipasi dalam pameran atau pertemuan industri grosir, sederhanakan siklus penjualan; (2) Berikan penawaran special untuk pelanggan baru; (3) mempercepat proses pemesanan dan pengiriman; (4) membuat produk di situs website.

\section{Daftar Pustaka}

Alzomaia, T. S. (2014). Capital structure determinants of publicly listed companies in Saudi Arabia. The International Journal of Business and Finance Research, 8(2), 53-67.

Antwi, S., Mills, E. F. E. A., \& Zhao, X. (2012). Capital structure and firm value: Empirical evidence from Ghana. International Journal of Business and Social Science, 3(22).

Arianto, T. (2008). Struktur Kepemilikan,
Profitabilitas, Pertumbuhan, Aktiva dan Ukuran Perusahaan Terhadap Struktur Modal Pada Perusahaan Manufaktur. Jurnal Keuangan Dan Perbankan, 12(1).

Atmaja, L. S. (2008). Dasar-dasae Pembelanjaan Perusahaan.

Yogyakarta: BPFE.

Barton, S. L., Hill, N. C., \& Sundaram, S. (1989). An empirical test of stakeholder theory predictions of capital structure. Financial Management, 36-44.

Brailsford, T. J., Oliver, B. R., \& Pua, S. L. (2000). Theory and evidence on the relationship between ownership structure and capital structure.

Brealey, R., Myers, S., \& Marcus, A. (2007). Dasar-Dasar Manajemen Keuangan Perusahaan (Edisi Lima). Erlangga.

Brigham, E. F., \& Houston, J. F. (2001). Manajemen Keuangan (Edisi 8 Buku 2). Jakarta: Erlangga.

Brigham, E. F., \& Houston, J. F. (2010). Dasar-dasar Manajemen Keuangan (Edisi 10). Jakarta: Salemba Empat.

Brigham, E. F., \& Houston, J. F. (2011). Dasar-dasar Manajemen Keuangan (Edisi 10). Jakarta: Salemba Empat.

Cahyo, A. N., Ardika, R., Saputra, J., \& Wijaya, T. (2014). Acceleration on the growth of rubber planting materials by using foliar application of humic acid. AGRIVITA, Journal of Agricultural Science, 36(2), 112-119.

De Propris, L., \& Driffield, N. (2005). The importance of clusters for spillovers from foreign direct investment and technology sourcing. Cambridge 
Journal of Economics, 30(2), 277291.

Deviani, M. Y., \& Sudjarni, L. K. (2018). Pengaruh Tingkat Pertumbuhan, Struktur Aktiva, Profitabilitas, dan Likuiditas Terhadap Struktur Modal Perusahaan Pertambangan di BEI. EJurnal Manajemen Universitas Udayana, $7(3)$.

Fahmi, I. (2012). Analisis Laporan Keuangan. Bandung: Alfabeta.

Ghozali, I. (2011). Aplikasi Analisis Multivariate Dengan Program SPSS. Semarang: Badan Penerbit Universitas Diponegoro.

Gitman, J. L. (2000). Principles of Mangerial Finance (10th Edition). USA: SanDiego State University.

Halim, Abdul. (2015). Auditing (DasarDasar Audit Laporan Keuangan)(Edisi Kelima).Yogyakarta: UPP STIM YKPN.

Harmono. (2009). Manajemen Keuangan Berbasis Balanced Scorecard (Pendekatan Teori, Kasus, dan Risset Bisnis). Jakarta: Bumi Aksara.

Hartono, J. (2000). Teori Portofolio dan Analisis Ivestasi (Edisi Kedua). Yogyakarta: BPFE.

Hasnawati, S. (2005). Dampak set peluang investasi terhadap nilai perusahaan publik di Bursa Efek Jakarta. Jurnal Fakultas Hukum UII, 9(2).

Hery. (2016). Analisis Laporan Keuangan. Jakarta: Grasindo.

Ismaida, P., \& Saputra, M. (2016). Pengaruh Pertumbuhan Penjualan,
Profitabilitas, Ukuran, Dan Aktivitas Perusahaan Terhadap Struktur Modal Pada Perusahaan Property Dan Real Estate Yang Terdaftar Di BEI Periode 2012-2014. Jurnal IImiah Mahasiswa Ekonomi Akuntansi, 1(1), 221-229.

Jensen, M. C. (1969). Risk, the pricing of capital assets, and the evaluation of investment portfolios. Journal of business, 42(2), 167-247.

Jensen, M. C. (1986). Agency Costs of Free Cash Flow, Corporate Finance, and Takeovers. American Economic Review, 76(2), 323-329.

Kaaro, H. (2003). Prediksi Struktur Modal Berbasis Pecking Order Theory Pada Kondisi Ekonomi Normal dan Ekonomi Krisis. Kajian Bisnis STIE Widya Wiwaha Yogyakarta, No. 28 (Ja, 51-66.

Kesuma, A. (2009). Analisis Faktor yang Mempengaruhi Struktur Modal Serta Pengaruhnya Terhadap Harga Saham Perusahaan Real Estate yang Go Public di Bursa Efek Indonesia. Jurnal manajemen dan Kewirausahaan, 11(1), 38-45.

Mayangsari, S. (2017). Analisis faktor-faktor yang mempengaruhi keputusan pendanaan perusahaan: Pengujian pecking order hyphotesis. Media Riset Akuntansi, Auditing \& Informasi, 1(3), 1-26.

Nugrahani, S. M., \& Sampurno, R. D. (2012). Analisis Pengaruh Profitabilitas, Likuiditas, pertumbuhan Penjualan, Ukuran perusahaan dan Kepemilikan Manajerial Terhadap Struktur Modal (Pada Perusahaan Manufaktur yang terdaftar di Bursa Efek Indonesia periode 2008- 2010). Diponegoro 
Business Review.

Pandey, K. D., \& Sahu, T. N. (2017). An empirical analysis on capital structure, ownership structure and firm performance: Evidence from India. Indian Journal of Commerce and Management Studies, 8(2), 63.

Pradana, A., \& Salehudin, I. (2013). Role of work overload toward turnover intention among newly hired public accountants.

Riyanto, B. (2001). Dasar-dasar Pembelanjaan Perusahaan.

Yogyakarta: BPFE.

Riyanto, B. (2004). Dasar-dasar Pembelanjaan Perusahaan (Edisi ke4). Yogyakarta: BPFE.

Said, H. B. (2013). Impact of ownership structure on debt equity ratio: A static and a dynamic analytical framework. International Business Research, 6(6), 162.

Sartono, A. (2001). Manajemen Keuangan Teori dan Aplikasi. Yogyakarta: BPFE- YOGYAKARTA.

Sartono, A. (2014). Manajemen Keuangan: Teori dan Aplikasi (Edisi Keempat). Yogyakarta: BPFE.

Sawir, A. (2004). Analisis Kinerja Keuangan dan Perencanaan Keuangan Perusahaan. Jakarta: PT Gramedia Pustaka Utama.

Schoubben, F., \& Van Hulle, C. (2004). The Determinants of Leverage; Differences Between Quoted and Non Quoted Firms. DTEW Research Report 0450, 1-32.

Sugiono, L. P., \& Christiawan, Y. J. (2013).
Analisis Faktor yang Mempengaruhi Likuiditas Pada Industri Ritel yang Terdaftar Pada Bursa Efek Indonesia Tahun 2007-2012. Jurnal Business Accounting Review, Vo. 1, No., Hal 298-305.

Suherli, M., \& Harahap, S. S. (2007). Studi Empiris Terhadap Faktor Penentu Kebijakan Jumlah Dividen. Media Riset Akuntansi, Auditing \& Informasi, 4(3), 223-245.

Suwito, E., \& Herawaty, A. (2005). Analisis Pengaruh Karakteristik Perusahaan Terhadap Tindakan Perataan Laba Yang Dilakukan Oleh Perusahaan Yang Terdaftar Di Bursa Efek Jakarta. Simposium Nasional Akuntansi, VIII(Solo, $15-16$ September).

Titman, S., \& Wessels, R. (1988). The determinants of capital structure choice. The Journal of Finance, 43(1), 1-19.

Wahyudi, U., \& Pawestri, H. P. (2006). Implikasi Struktur Kepemilikan Terhadap Nilai Perusahaan: Dengan Keputusan Keuangan Sebagai Variabel Intervening. Simposium Nasional Akuntansi, 9, 1-25.

Wald, J. K. (1999). How firm characteristics affect capital structure: an international comparison. Journal of Financial research, 22(2), 161-187.

Weston, J. F., \& Thomas, E. C. (1997). Manajemen Keuangan Jilid 1 .dialih bahasakan oleh Jaka Wasana dan Kibrandoko. (J. Wasana \& Kibrandoko, Eds.) (Edisi 1). Jakarta: Binarupa Aksara.

Wiagustini, N. L. P. (2010). Dasar-dasar Manajemen Keuangan. Denpasar: 
Udayana University Press.

Wild, J. J., Subramanyam, K. R., \& Halsey, R. F. (2005). Analisis Laporan Keuangan (Edisi Kede). Jakarta: Salemba Empat.

Yudiandari, C. I. D. (2018). Pengaruh Profitabilitas, Operating Leverage, Ukuran Perusahaan dan Pertumbuhan Penjualan pada Struktur Modal. E-Jurnal Akuntansi Universitas Udayana, 22(1), 408-437. 